\title{
A STUDY ON PHYSICOCHEMICAL PROPERTIES OF SOILS UNDER DIFFERENT TEA GROWING REGIONS OF WEST BENGAL (INDIA)
}

\section{RAY S.K. AND MUKHOPADHYAY D.*}

Department of Soil Science and Agricultural Chemistry, Uttar Banga Krishi Viswavidyalaya, Pundibari, CoochBehar- 736165, WB, India. *Corresponding Author: Email- dibsm107@gmail.com

Received: March 08, 2012; Accepted: December 10, 2012

\begin{abstract}
The physicochemical properties of soil $(0-0.20 \mathrm{~m})$ were analysed to evaluate the characteristics of tea growing soils under three different locations of West Bengal (India), considering the age and elevation of tea plantation. The soil samples of Dooars and Terai region of West Bengal were collected on the basis of age (young, medium and old) of the tea plants, while that from Darjeeling region as organic and non-organic tea growing soils. The organic and non-organic tea soils were collected on the basis of elevations of the sites. The soils of the Dooars region were clay to sandy loam in texture whereas, soils of Terai and Darjeeling were sandy loam in texture. The selected soils were strong to moderately acidic in reaction with low electrical conductivity $(\mathrm{EC}), \mathrm{Ca}^{+2}$ and $\mathrm{Mg}^{+2}$ content. The organic carbon content of different regions was found medium to high, but very little variation was obtained with organic tea growing regions of Darjeeling. The soil available $\mathrm{N}$ and $\mathrm{P}$ content were low to medium in all the regions but higher available $\mathrm{K}$ content were found with the soils of Dooars and Terai regions. The cation exchange capacity (CEC) of soils varied from low to medium. The correlation study indicated that CEC, available $\mathrm{N}$ and $\mathrm{K}$ were influenced by soil organic carbon content, while the available $\mathrm{P}, \mathrm{Ca}^{+2}$ and $\mathrm{Mg}^{+2}$ content by the soil $\mathrm{pH}$. The available $\mathrm{N}, \mathrm{K}$, EC and CEC were negatively influenced by sand content of the soils.
\end{abstract}

Keywords- Physicochemical, electrical conductivity, texture and cation exchange capacity

Citation: Ray S.K. and Mukhopadhyay D. (2012) A Study on Physicochemical Properties of Soils Under Different Tea Growing Regions of West Bengal (India). International Journal of Agriculture Sciences, ISSN: 0975-3710 \& E-ISSN: 0975-9107, Volume 4, Issue 8, pp-325-329.

Copyright: Copyright@2012 Ray S.K. and Mukhopadhyay D. This is an open-access article distributed under the terms of the Creative Commons Attribution License, which permits unrestricted use, distribution and reproduction in any medium, provided the original author and source are credited.

\section{Introduction}

In West Bengal tea grows mostly in the districts of Darjeeling and Jalpaiguri. The major river (Jaldhaka, Tista, Torsha, Raidak, Sankosh) basin under North Bengal situation have large catchment area in the hills where the rivers cut down the ridge and mountain to come down to the plains of Terai and Dooars area [1]. In Darjeeling district, tea is mainly grown in regions of mountain slopes at an altitude of 2,000 metres and in Jalpaiguri district, it is grown mainly in Terai and Dooars regions. These sub-mountain tracts are characterized by deep steep sided valley, separated by terraced high lands, immediately to the south of the Himalayas. Tea naturally grows in tropical to temperate conditions, where the annual rainfall is more than $200 \mathrm{~cm}$ [2]. Tea performs best under acid soil conditions with well drained sloping ground and porous soil status for independent utilization and adsorption of nutrients. Tea grows well within the range of ideal physical and environmental conditions having heterogeneous soil and climatic conditions, for which tea growing regions/soils becomes fairly wide in character, that influence the soil physical and chemical nature. Evaluations of soil fertility status under tea growing soils are necessary to make a proper management and sound fertilizer recommendation for optimizing the yield of tea. Some of the areas in the lower foot hills below the Piedmont zone are prone to deposition of alluvial sediments and sands [3]. Hence, an attempt was made to study the important physicochemical properties of soils collected on the basis of age and elevation of the tea-plants under different tea growing regions of West Bengal.

\section{Materials and Methods}

Fifty four surface soil $(0-0.2 \mathrm{~m})$ samples from eighteen tea gardens comprising six from each region were collected from two districts, namely, Jalpaiguri and Darjeeling of West Bengal. The soils of the Dooars and Terai region under Jalpaiguri districts were collected considering the age of the tea- plants (Young i.e., 10-20years, Medium i.e. 20-40 years and Old i.e., more than 50 years), while that from Darjeeling as organic and non-organic tea growing soils. The organic and non-organic tea soils were collected on the basis of elevations (low, medium and high) of the tea plantation. Soil samples were collected from Lakhipara, Haldibari, Nagrakata, Ghatia, Chalouni and Batabari tea gardens under Dooars region, while from the Terai region, Hansqua, Taipoo, Sayedabad, Mothidhar, Gayaganga and Lohagarh gardens were selected for collection of soil samples. Soil samples were collected from non-organic gardens of Darjeeling and under Dooars and Terai region. The 
Sungma, Salimbong and Avongrove tea gardens were selected as organic and Glenburn, Bernesbeg and Namring as non-organic tea gardens. The important parameters $(\mathrm{pH}, \mathrm{EC}$, texture, available- $\mathrm{N}$, $\mathrm{P}$ and $\mathrm{K}, \mathrm{CEC}$, exchangeable $\mathrm{Ca}^{+2}$ and $\mathrm{Mg}^{+2}$ ) were determined following the standard methodology [4].

\section{Statistical Analysis}

Data were analysed statistically by using the software SPSS (Version 12.0).

\section{Results and Discussion}

\section{Physicochemical Properties of Soils of Dooars Area}

The soils $(0-20 \mathrm{~cm})$ were recorded to be strong to moderately acidic in reaction [Table-1] and non-saline in nature. The soils varied from clay to sandy loam in texture. Among the six tea gardens of Dooars regions, the soils of Nagrakata and Ghatia tea garden were predominantly clay to clay loam in texture, whereas, the soils of Lakhipara, Haldibari, Chalouni and Batabari were sandy loam to sandy clay loam in texture. The organic carbon varied from 19.4 to $28.4 \mathrm{~g} \mathrm{~kg}^{-1}$ in young, 14.9 to $28.4 \mathrm{~g} \mathrm{~kg}^{-1}$ in medium and 15.4 to 26.5 $\mathrm{g} \mathrm{kg}^{-1}$ in old aged soils of Dooars region. The organic carbon was found relatively higher in young aged section of Ghatia and medium aged section of Chalouni tea garden. The cation exchange capacity (CEC) was low to medium and varied from 5.38 to 11.17 $\mathrm{cmol}\left(\mathrm{p}^{+}\right) \mathrm{kg}^{-1}$ in young, 5.11 to $13.8 \mathrm{cmol}\left(\mathrm{p}^{+}\right) \mathrm{kg}^{-1}$ in medium and 4.39 to $11.56 \mathrm{cmol}\left(\mathrm{p}^{+}\right) \mathrm{kg}^{-1}$ in old aged sections. The CEC of the medium aged sections of Nagrakata tea soil was higher, might be due to the presence of higher clay and least was in young aged sections of Batabari tea soil. The soil available $\mathrm{N}$ content varied from 78.56 to $203.55 \mathrm{~kg} \mathrm{ha}^{-1}$ in the young, 78.56 to $245.55 \mathrm{~kg} \mathrm{ha}^{-1}$ in medium and 95.96 to $202.59 \mathrm{~kg} \mathrm{ha}^{-1}$ in old aged sections of Dooars. The available nitrogen status of all the soils were generally low to medium and this variation might be due to leaching loss of $\mathrm{N}$ from the surface soil. Available $P$ content varied between 17.25 to $51.22 \mathrm{~kg} \mathrm{ha}^{-1}$ in young, 19.22 to $56.73 \mathrm{~kg} \mathrm{ha}^{-1}$ in medium and 12.56 to $56.73 \mathrm{~kg} \mathrm{ha}^{-1}$ in old aged soils of Dooars. Higher P content was found with medium aged section of Lakhipara and the least was with old aged sections of Batabari. The available $\mathrm{K}$ content was found medium to high. Maximum potassium content was found with medium aged section of Nagrakata and the least was with young aged sections of Batabari tea soil.

Table 1- Important physicochemical properties of soils $(0-20 \mathrm{~cm})$ of Dooars tea - growing region of Jalpaiguri Districts

\begin{tabular}{|c|c|c|c|c|c|c|c|c|c|c|c|c|c|c|}
\hline $\begin{array}{l}\text { Name of the } \\
\text { Gardens }\end{array}$ & $\begin{array}{c}\text { Age } \\
\text { (years) }\end{array}$ & $\begin{array}{l}\text { Clay } \\
(\%)\end{array}$ & $\begin{array}{l}\text { Silt } \\
(\%)\end{array}$ & $\begin{array}{l}\text { Sand } \\
(\%)\end{array}$ & Texture & $\underset{(1: 2.5)}{\mathrm{pH}}$ & $\begin{array}{c}\mathrm{EC} \\
\left(\mathrm{dSm} \mathrm{m}^{-1}\right)\end{array}$ & $\begin{array}{c}\text { Organic Carbon } \\
\left(\mathrm{g} \mathrm{kg}^{-1}\right)\end{array}$ & $\begin{array}{l}\text { Available-N } \\
\left(\mathrm{kg} \mathrm{ha}^{-1}\right)\end{array}$ & $\begin{array}{c}\text { Available-P } \\
\left(\mathrm{kg} \mathrm{ha}^{-1}\right)\end{array}$ & $\begin{array}{l}\text { Available-K } \\
\left(\mathrm{kg} \mathrm{ha}^{-1}\right)\end{array}$ & $\begin{array}{l}\text { CEC [cmol } \\
\left.(p+) \mathrm{kg}^{-1}\right]\end{array}$ & $\begin{array}{l}\mathrm{Ca}^{+2}\left[\mathrm{cmol}^{-1}\right. \\
\left.(\mathrm{p}+) \mathrm{kg}^{-1}\right]\end{array}$ & $\begin{array}{c}\mathrm{Mg}^{+2}\left[\mathrm{cmol}^{2}\right. \\
\left.(\mathrm{p}+) \mathrm{kg}^{-1}\right]\end{array}$ \\
\hline & $10-20$ & 16.6 & 26.2 & 57.2 & Sandy Loam & 4.61 & 0.18 & 19.4 & 99.45 & 17.25 & 214.67 & 6.22 & 1.56 & 0.1 \\
\hline \multirow[t]{3}{*}{ Lakhipara } & $20-40$ & 16.6 & 20.2 & 63.2 & Sandy Loam & 4.97 & 0.15 & 19.8 & 102.56 & 56.73 & 261.33 & 8.56 & 0.15 & 0.12 \\
\hline & $>50 \mathrm{yrs}$. & 32.6 & 20.2 & 47.2 & Sandy Clay & 4.94 & 0.14 & 25.5 & 95.96 & 55.32 & 373.33 & 12.56 & 0.23 & 0.18 \\
\hline & $10-20$ & 16.6 & 18.2 & 65.2 & Sandy Loam & 4.93 & 0.25 & 19.5 & 78.56 & 51.22 & 289.33 & 7.12 & 0.12 & 0.91 \\
\hline \multirow[t]{3}{*}{ Haldibari } & $20-40$ & 18.6 & 26.2 & 55.2 & Sandy Loam & 4.84 & 0.12 & 14.9 & 78.56 & 43.04 & 153.07 & 8.54 & 0.23 & 0.91 \\
\hline & $>50 \mathrm{yrs}$. & 20.6 & 16.2 & 63.2 & Sandy Clay loam & 4.62 & 0.13 & 15.4 & 106.62 & 30.56 & 168 & 9.56 & 0.89 & 0.37 \\
\hline & $10-20$ & 30 & 29 & 41 & Clay Loam & 4.48 & 0.12 & 19.9 & 111.96 & 25.66 & 392 & 12.56 & 0.74 & 0.4 \\
\hline \multirow[t]{3}{*}{ Nagrakata } & $20-40$ & 35 & 39 & 26 & Clay & 4.6 & 0.11 & 22.7 & 116.25 & 30.12 & 709.33 & 13.8 & 1.11 & 2.29 \\
\hline & $>50 \mathrm{yrs}$. & 32.6 & 28.2 & 39.2 & Clay & 4.33 & 0.22 & 17 & 102.56 & 22.55 & 298.67 & 12.11 & 2.42 & 0.51 \\
\hline & $10-20$ & 39 & 36 & 25 & Clay & 4.62 & 0.09 & 28.4 & 159.94 & 29.34 & 599.83 & 10.75 & 1.22 & 3.02 \\
\hline \multirow[t]{3}{*}{ Ghatia } & $20-40$ & 38 & 38 & 24 & Clay & 4.42 & 0.09 & 15.1 & 89.56 & 23.12 & 401.33 & 11.47 & 2.56 & 0.61 \\
\hline & $>50 \mathrm{yrs}$. & 26 & 29 & 45 & Clay Loam & 4.46 & 0.05 & 26.5 & 202.59 & 25.22 & 476 & 8.56 & 1.25 & 0.4 \\
\hline & $10-20$ & 48.6 & 20.2 & 31.2 & Clay & 4.6 & 0.07 & 22.7 & 203.55 & 23.22 & 289.33 & 11.2 & 2.92 & 0.19 \\
\hline \multirow[t]{3}{*}{ Chalouni } & $20-40$ & 24.6 & 20.2 & 55.2 & Sandy Clay loam & 4.7 & 0.05 & 28.4 & 245.55 & 19.22 & 429.33 & 7.88 & 3.23 & 1.24 \\
\hline & $>50 \mathrm{yrs}$. & 26 & 34 & 40 & Clay Loam & 4.7 & 0.08 & 20.8 & 154.6 & 29.56 & 476 & 8.6 & 3.33 & 0.82 \\
\hline & $10-20$ & 19 & 27 & 54 & Sandy Loam & 4.68 & 0.12 & 20.8 & 127.95 & 33.25 & 130.67 & 5.38 & 1.22 & 0.09 \\
\hline \multirow[t]{2}{*}{ Batabari } & $20-40$ & 22 & 27 & 51 & Sandy Clay Loam & 4.45 & 0.11 & 17 & 127.95 & 26.25 & 181.07 & 7.44 & 2.66 & 0.27 \\
\hline & $>50 \mathrm{yrs}$. & 23 & 39 & 38 & Clay Loam & 4.4 & 0.09 & 17 & 109.94 & 12.56 & 143.73 & 7.23 & 2.56 & 0.09 \\
\hline
\end{tabular}

The soil pH was positively correlated [Table-2] with available phosphorus $\left(r=0.855^{* *}\right)$ and sand content $\left(r=0.544^{*}\right)$ and negative correlation was obtained with silt $\left(r=-0.555^{*}\right)$ and available calcium $\left(r=-0.582^{*}\right)$. The EC had a negative correlation with available nitrogen $\left(r=-0.696^{* *}\right)$. The sand content had significant negative correlation with CEC $\left(r=-0.631^{* *}\right)$ and potassium $\left(r=-0.612^{*}\right)$. Soil organic carbon had a significant positive correlation with available nitrogen $\left(r=0.711^{* *}\right)$ and available potassium $\left(r=0.629^{* *}\right)$, suggesting that soil organic carbon increased the availability of nutrients under tea growing soils. Strong and positive correlation was observed between cation exchange capacity and clay content $(r=$ $0.748^{* *}$ ) which indicated the cations adsorption at the exchange sites of the clay. The CEC had also positive correlation with available potassium content $\left(r=0.604^{*}\right)$. The available calcium content had a significant positive correlation with available nitrogen $(r=$ $\left.0.543^{*}\right)$ and negative correlation with available phosphorus $(r=-$ $\left.0.742^{* *}\right)$. The significant positive correlation was observed between magnesium and available potassium $\left(r=0.744^{\star *}\right)$ of the soil.
Table 2- Correlation matrix among soil physicochemical properties under Dooars region

\begin{tabular}{|c|c|c|c|c|c|c|c|c|c|}
\hline $\begin{array}{l}\text { Soil } \\
\text { Properties }\end{array}$ & Clay & Silt & Sand & $\mathrm{pH}$ & EC & OC & $\mathrm{N}$ & $\mathbf{P}$ & K \\
\hline Sand & $-0.853^{* *}$ & $-0.763^{* *}$ & 1 & & & & & & \\
\hline pH & NS & $-0.555^{*}$ & $0.544^{\star}$ & 1 & & & & & \\
\hline $\mathrm{N}$ & NS & NS & NS & NS & $-0.696^{* *}$ & $0.711^{\star *}$ & 1 & & \\
\hline$P$ & NS & $-0.471^{\star}$ & NS & $0.855^{\star *}$ & NS & NS & NS & 1 & \\
\hline K & $0.545^{\star}$ & NS & $-0.612^{* \star}$ & NS & NS & $0.629^{\star \star}$ & NS & NS & 1 \\
\hline CEC & $0.748^{* *}$ & NS & $-0.631^{* *}$ & NS & NS & NS & NS & NS & $0.604^{* \star}$ \\
\hline $\mathrm{Ca}^{+2}$ & NS & NS & NS & $-0.582^{*}$ & NS & NS & $0.543^{\star}$ & $-0.742^{* *}$ & NS \\
\hline $\mathrm{Mg}^{+2}$ & NS & NS & NS & NS & NS & NS & NS & NS & $0.744^{* *}$ \\
\hline
\end{tabular}

* Significant at 5\% level; ** Significant at 1\% level

\section{Physicochemical Properties of Soils Under Terai Region}

Soils of Terai were strong to moderately acidic [Table-3] in reaction with low EC. Soils were sandy loam to clay in texture. The clay content varied from 7.6 to 20.0 percent in young, 6.6 to 40.4 percent in medium and 6.6 to 20.4 percent in old aged sections. The 
organic carbon content under Terai region varied from 15.1 to 41.2 $\mathrm{g} \mathrm{kg}^{-1}$ in young, 17.4 to $44.6 \mathrm{~g} \mathrm{~kg}^{-1}$ in medium and 15.9 to $43.1 \mathrm{~g} \mathrm{~kg}$ ${ }^{-1}$ in old aged soils. The highest organic carbon was obtained with Lohagarh tea garden and the lowest in Hansqua tea estate. The CEC was low to medium in Terai soils under study and it varied from 4.20 to $9.79 \mathrm{cmol}\left(\mathrm{p}^{+}\right) \mathrm{kg}^{-1}$ in young, 4.55 to $10.60 \mathrm{cmol}\left(\mathrm{p}^{+}\right) \mathrm{kg}$

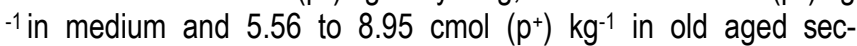
tions. The highest CEC was obtained with medium aged sections of Mothidhar, might be due to higher clay content, and least with young aged sections of Sayedabad. The available soil $\mathrm{N}$ content varied from 47.04 to $210.74 \mathrm{~kg} \mathrm{ha}^{-1}$ in the young, 40.32 to 226.12 $\mathrm{kg} \mathrm{ha}^{-1}$ in medium and 65.86 to $286.00 \mathrm{~kg} \mathrm{ha}^{-1}$ in old aged sections Available P content varied between 3.91 to $41.08 \mathrm{~kg} \mathrm{ha}^{-1}$ in young, 1.96 to $32.55 \mathrm{~kg} \mathrm{ha}^{-1}$ in medium and 3.91 to $22.12 \mathrm{~kg} \mathrm{ha}^{-1}$ in old aged soils and wide variation of soil available $P$ might be due to the fixation of $P$ in soil as insoluble aluminium and iron phosphate. Available $\mathrm{K}$ content under Terai region varied from the medium to high. Higher potassium content was found in both medium and young aged sections of Hansqua and Taipoo tea soils respectively. The $\mathrm{Ca}^{+2}$ and $\mathrm{Mg}^{+2}$ content were low, might be due to higher acidity and poor application of liming materials in soils.

Table 3- Important physicochemical properties of soils $(0-20 \mathrm{~cm})$ under Terai tea - growing region of Jalpaiguri Districts

\begin{tabular}{|c|c|c|c|c|c|c|c|c|c|c|c|c|c|c|}
\hline $\begin{array}{l}\text { Name of the } \\
\text { Gardens }\end{array}$ & $\begin{array}{l}\text { Age } \\
\text { (years) }\end{array}$ & $\begin{array}{l}\text { Clay } \\
(\%)\end{array}$ & $\begin{array}{l}\text { Silt } \\
(\%)\end{array}$ & $\begin{array}{l}\text { Sand } \\
(\%)\end{array}$ & ture & $\begin{array}{c}\mathrm{pH} \\
(1: 2.5)\end{array}$ & $\begin{array}{l}\mathrm{EC} \\
\left(\mathrm{dS} \mathrm{m}^{-1}\right)\end{array}$ & $\begin{array}{l}\text { Organic Carbon } \\
\left(\mathrm{g} \mathrm{kg}^{-1}\right)\end{array}$ & $\begin{array}{l}\text { Available-N } \\
\left(\mathrm{kg} \mathrm{ha}^{-1}\right)\end{array}$ & $\begin{array}{c}\text { Available-P } \\
\left(\mathrm{kg} \mathrm{ha}^{-1}\right)\end{array}$ & $\begin{array}{l}\text { Available-K } \\
\left(\mathrm{kg} \mathrm{ha}^{-1}\right)\end{array}$ & $\begin{array}{c}\text { CEC [cmol } \\
\left.(p+) \mathrm{kg}^{-1}\right]\end{array}$ & $\begin{array}{c}\mathrm{Ca}^{+2}[\mathrm{cmol} \\
\left.(\mathrm{p}+) \mathrm{kg}^{-1}\right]\end{array}$ & $\begin{array}{c}\left.\mathrm{Mg}^{+2}\left[\mathrm{cmol}^{-1}+\right) \mathrm{kg}^{-1}\right]\end{array}$ \\
\hline & $10-20$ & 8.6 & 26.2 & 65.2 & Sandy Loam & 4.35 & 0.05 & 17.3 & 47.04 & 6.25 & 448.00 & 7.89 & 0.25 & 0.41 \\
\hline \multirow[t]{3}{*}{ Hansqua } & $20-40$ & 6.6 & 27.2 & 66.2 & Sandy Loam & 4.70 & 0.03 & 18.9 & 105.23 & 22.56 & 485.33 & 8.89 & 2.16 & 1.22 \\
\hline & $>50 \mathrm{yrs}$ & 7.6 & 27.2 & 65.2 & Sandy Loam & 4.38 & 0.04 & 15.9 & 65.86 & 7.84 & 345.33 & 6.47 & 0.45 & 0.42 \\
\hline & $10-20$ & 7.6 & 25.2 & 67.2 & Sandy Loam & 4.41 & 0.05 & 15.1 & 98.56 & 9.22 & 485.33 & 9.79 & 0.77 & 0.33 \\
\hline \multirow[t]{3}{*}{ Taipoo } & $20-40$ & 7.6 & 19.2 & 73.2 & Sandy Loam & 4.42 & 0.06 & 17.4 & 40.32 & 8.92 & 235.44 & 4.55 & 1.22 & 1.22 \\
\hline & $>50 \mathrm{yrs}$ & 6.6 & 26.2 & 67.2 & Sandy Loam & 4.50 & 0.07 & 23.5 & 89.25 & 19.25 & 373.33 & 7.97 & 1.03 & 1.03 \\
\hline & $10-20$ & 18.4 & 19.2 & 62.6 & Sandy Loam & 4.38 & 0.02 & 15.6 & 108.45 & 41.08 & 242.67 & 4.20 & 0.57 & 0.33 \\
\hline \multirow[t]{3}{*}{ Sayedabad } & $20-40$ & 14.0 & 20.4 & 65.6 & Sandy Loam & 4.65 & 0.03 & 19.4 & 180.63 & 32.55 & 317.33 & 5.62 & 1.23 & 0.66 \\
\hline & $>50 \mathrm{yrs}$ & 12.0 & 22.8 & 65.2 & Sandy Loam & 4.36 & 0.05 & 17.5 & 125.45 & 3.91 & 164.27 & 6.90 & 0.23 & 1.26 \\
\hline & $10-20$ & 20.0 & 34.0 & 46.0 & Clay Loam & 4.75 & 0.09 & 27.6 & 126.50 & 24.45 & 189.23 & 8.99 & 1.55 & 2.01 \\
\hline \multirow[t]{3}{*}{ Mothidhar } & $20-40$ & 40.4 & 21.6 & 38.0 & Clay & 4.33 & 0.08 & 22.4 & 133.54 & 20.54 & 448.00 & 10.60 & 0.25 & 0.65 \\
\hline & $>50 \mathrm{yrs}$ & 20.4 & 21.6 & 58.0 & Sandy Clay Loam & 4.40 & 0.05 & 23.5 & 122.56 & 22.12 & 322.56 & 7.30 & 0.63 & 0.36 \\
\hline & $10-20$ & 14.0 & 28.8 & 57.2 & Sandy Loam & 4.13 & 0.02 & 17.9 & 98.26 & 14.67 & 420.00 & 6.10 & 0.44 & 0.23 \\
\hline \multirow[t]{3}{*}{ Gayaganga } & $20-40$ & 16.4 & 11.6 & 72.0 & Sandy Loam & 4.80 & 0.03 & 20.9 & 122.45 & 25.22 & 261.33 & 4.56 & 1.25 & 0.21 \\
\hline & $>50 \mathrm{yrs}$ & 20.0 & 26.4 & 53.6 & Sandy Clay Loam & 4.00 & 0.05 & 18.9 & 102.56 & 10.22 & 420.00 & 8.95 & 0.44 & 0.13 \\
\hline & $10-20$ & 16.0 & 17.6 & 66.4 & Sandy Loam & 4.30 & 0.06 & 41.2 & 210.74 & 3.91 & 298.67 & 7.80 & 0.36 & 0.37 \\
\hline \multirow[t]{2}{*}{ Lohagarh } & $20-40$ & 12.0 & 27.6 & 60.4 & Sandy Loam & 4.25 & 0.07 & 44.6 & 226.12 & 1.96 & 280.00 & 7.70 & 1.35 & 0.13 \\
\hline & $>50 \mathrm{yrs}$ & 12.0 & 14.4 & 73.6 & Sandy Loam & 4.10 & 0.02 & 43.1 & 286.00 & 7.25 & 2.13 & 5.56 & 0.58 & 0.26 \\
\hline
\end{tabular}

The $\mathrm{pH}$ had a significant positive correlation [Table-4] with available $P\left(r=0.538^{*}\right)$, Calcium $\left(r=0.677^{* *}\right)$ and Magnesium $(r=$ $\left.0.554^{*}\right)$, which indicated that availability of $\mathrm{P}, \mathrm{Ca}^{+2}$ and $\mathrm{Mg}^{+2}$ were dependent on soil acidity. Sand content had significant negative correlation with EC $\left(r=-0.529^{*}\right)$ and CEC $\left(r=-0.609^{*}\right)$. The EC was positively related to CEC $\left(r=0.616^{* *}\right)$ and $\mathrm{Mg}^{+2}\left(0.473^{*}\right)$. Strong and positive correlation was observed between organic carbon and available $\mathrm{N}\left(\mathrm{r}=0.852^{* *}\right)$ and negative correlation with available $\mathrm{K}$ $\left(r=-0.488^{*}\right)$. The CEC had the significant positive correlation with silt $\left(r=0.557^{*}\right)$, EC $\left(r=0.616^{\star *}\right)$ and available $K\left(r=0.558^{*}\right)$.

Table 4- Correlation matrix among soil physicochemical properties under Terai regions

\begin{tabular}{|c|c|c|c|c|c|c|c|c|}
\hline $\begin{array}{l}\text { Soil } \\
\text { Properties }\end{array}$ & Clay & Silt & Sand & pH & EC & $O C$ & $\mathbf{N}$ & K \\
\hline Sand & $-0.802^{* *}$ & $-0.491^{*}$ & 1 & & & & & \\
\hline EC & NS & NS & $-0.529^{*}$ & NS & 1 & & & \\
\hline $\mathrm{N}$ & NS & NS & NS & NS & NS & $0.852^{* *}$ & 1 & \\
\hline$P$ & NS & NS & NS & $0.538^{\star *}$ & NS & NS & NS & \\
\hline K & NS & NS & NS & NS & NS & $-0.488^{*}$ & $-0.545^{\star}$ & 1 \\
\hline CEC & NS & $0.557^{*}$ & $-0.609^{* *}$ & NS & $0.616^{* *}$ & NS & NS & $0.558^{*}$ \\
\hline $\mathrm{Ca}^{+2}$ & NS & NS & NS & $0.677^{\star \star}$ & NS & NS & NS & NS \\
\hline $\mathrm{Mg}^{+2}$ & NS & NS & NS & $0.554^{*}$ & $0.473^{*}$ & NS & NS & NS \\
\hline
\end{tabular}

* Significant at $5 \%$ level; ** Significant at $1 \%$ level

\section{Physicochemical Properties Under Organic Tea Growing Soils of Darjeeling}

Soils of organic tea growing gardens were found to be strong to moderately acidic in reaction, with low electrical conductivity (EC), might be due to leaching of soluble salts by heavy rainfall. Soils under study were sandy loam to sandy clay loom in texture and the clay content varied from 14.8 to $20.8,14.8$ to 18.8 and 16.8 to 22.8 percent at the low medium and high elevations respectively [Table 5]. Data pertaining to CEC ranged from 5.89 to $8.88,5.97$ to 8.96 and 5.89 to $13.89 \mathrm{cmol}(\mathrm{p}+) \mathrm{kg}^{-1}$ in soils of low, medium and high elevations respectively.

The organic carbon content was high and ranged between 20.3 and $37.6,19.1$ and 29.9 and 21.3 and $28.6 \mathrm{~g} \mathrm{~kg}^{-1}$ of soils in low, medium and high elevations respectively and these variations might be due to the effect of management practices of these locations. The available $\mathrm{N}$ content varied from 40.14 to $189.63 \mathrm{~kg} \mathrm{ha}^{-1}$ in low, 30.11 to $89.53 \mathrm{~kg} \mathrm{ha}^{-1}$ in medium and 42.65 to $142.20 \mathrm{~kg} \mathrm{ha}-$ 1 in high elevations respectively. The lower available $\mathrm{N}$ in soil was found, might be due to less mineralization under low temperature conditions. The availability of soil P varied from 17.20 to $150.26 \mathrm{~kg}$ $\mathrm{ha}^{-1}, 18.14$ to $22.80 \mathrm{~kg} \mathrm{ha}^{-1}$ and 5.11 to $49.30 \mathrm{~kg} \mathrm{ha}^{-1}$ under low, medium and high elevations respectively. The higher availability of phosphorus under lower elevation was observed. The available soil potassium content in organic tea growing areas of the Darjeeling regions was low to medium and the $\mathrm{K}$ content varied from 122.36 to $325.67 \mathrm{~kg} \mathrm{ha}^{-1}, 105.23$ to $380.37 \mathrm{~kg} \mathrm{ha}^{-1}$ and 160.84 to 355.45 $\mathrm{kg} \mathrm{ha}^{-1}$ in low, medium and high elevations, respectively. The soil $\mathrm{Ca}^{+2}$ and $\mathrm{Mg}^{+2}$ content were found low in all the elevations.

Soil pH had a strong and positive correlation [Table-6] with Calcium $\left(r=0.891^{* *}\right)$ and Magnesium $\left(r=0.807^{* *}\right)$ and negative correlation with available nitrogen $\left(r=-0.484^{*}\right)$. The EC had a significant negative correlation with organic carbon $\left(r=-0.534^{*}\right)$, phosphorus $(r=-$ 
$\left.0.591^{*}\right)$ and available potassium $\left(r=-0.658^{*}\right)$. The CEC had a significant positive correlation with clay $\left(r=0.640^{*}\right)$, silt $\left(r=0.633^{*}\right)$ and potassium $\left(r=0.596^{*}\right)$ and significant negative correlation with sand content $\left(r=-0.775^{* *}\right)$. The strong and positive correlation was observed between $\mathrm{Ca}^{+2}$ and $\mathrm{Mg}^{+2}\left(\mathrm{r}=0.910^{* *}\right)$ under organic tea soil.

Table 5- Important physicochemical properties under organic tea growing soils $(0-20 \mathrm{~cm})$ of Darjeeling

\begin{tabular}{|c|c|c|c|c|c|c|c|c|c|c|c|c|c|c|}
\hline $\begin{array}{l}\text { Name of the } \\
\text { Gardens }\end{array}$ & $\begin{array}{l}\text { Elevation } \\
\text { (mt) }\end{array}$ & $\begin{array}{l}\text { Clay } \\
(\%)\end{array}$ & $\begin{array}{l}\text { Silt } \\
(\%)\end{array}$ & $\begin{array}{l}\text { Sand } \\
(\%)\end{array}$ & Texture & $\underset{(1: 2.5)}{\mathrm{pH}}$ & $\begin{array}{c}E C \\
\left(d S m^{-1}\right)\end{array}$ & $\begin{array}{l}\text { Organic Carbon } \\
\qquad\left(\mathrm{g} \mathrm{kg}^{-1}\right)\end{array}$ & $\begin{array}{l}\text { Available-N } \\
\left(\mathrm{kg} \mathrm{ha}^{-1}\right)\end{array}$ & $\begin{array}{l}\text { Available-P } \\
\left(\mathrm{kg} \mathrm{ha}^{-1}\right)\end{array}$ & $\begin{array}{c}\text { Available-K } \\
\left(\mathrm{kg} \mathrm{ha}^{-1}\right)\end{array}$ & $\begin{array}{l}\text { CEC [cmol } \\
\left.(p+) \mathrm{kg}^{-1}\right]\end{array}$ & $\begin{array}{c}\mathrm{Ca}^{+2}[\mathrm{cmol} \\
\left.(\mathrm{p}+) \mathrm{kg}^{-1}\right]\end{array}$ & $\begin{array}{c}\mathrm{Mg}^{+2}[\mathrm{cmol} \\
\left.(\mathrm{p}+) \mathrm{kg}^{-1}\right]\end{array}$ \\
\hline & 1137 & 14.8 & 16.2 & 69.0 & Sandy Loam & 4.56 & 0.02 & 37.6 & 189.36 & 150.26 & 322.25 & 5.89 & 0.03 & 0.04 \\
\hline \multirow[t]{2}{*}{ Sungma } & 1367 & 18.8 & 24.2 & 57.0 & Sandy Loam & 4.97 & 0.06 & 29.9 & 89.56 & 19.53 & 380.37 & 8.96 & 0.33 & 0.19 \\
\hline & 1214 & 17.8 & 15.2 & 67.0 & Sandy Loam & 5.21 & 0.02 & 23.7 & 40.14 & 27.44 & 325.67 & 8.88 & 0.25 & 0.09 \\
\hline \multirow[t]{2}{*}{ Salimbong } & 1446 & 20.8 & 14.2 & 65.0 & Sandy Clay Loam & 4.96 & 0.05 & 19.1 & 51.43 & 18.14 & 145.23 & 6.80 & 0.30 & 0.10 \\
\hline & 1534 & 16.8 & 22.2 & 61.0 & Sandy Loam & 5.32 & 0.06 & 21.3 & 42.65 & 11.16 & 204.31 & 5.89 & 0.43 & 0.27 \\
\hline \multirow[t]{2}{*}{ Avongrove } & 1149 & 14.8 & 18.2 & 67.0 & Sandy Loam & 4.31 & 0.09 & 21.0 & 30.11 & 22.80 & 105.23 & 5.97 & 0.02 & 0.03 \\
\hline & 1501 & 22.8 & 22.2 & 55.0 & Sandy Clay Loam & 4.53 & 0.06 & 28.6 & 142.20 & 5.11 & 160.84 & 8.56 & 0.12 & 0.04 \\
\hline
\end{tabular}

Table 6- Correlation matrix among soil physicochemical properties under organic tea growing regions of Darjeeling

\begin{tabular}{|c|c|c|c|c|c|c|c|c|c|}
\hline $\begin{array}{l}\text { Soil } \\
\text { Properties }\end{array}$ & Clay & Silt & Sand & pH & EC & $O C$ & $\mathbf{N}$ & K & $\mathrm{Ca}^{+2}$ \\
\hline Sand & $-0.716^{*}$ & $-0.889^{* \star}$ & 1 & & & & & & \\
\hline$O C$ & NS & NS & NS & NS & $-0.534^{*}$ & 1 & & & \\
\hline$N$ & NS & NS & NS & $-0.484^{*}$ & NS & $0.593^{*}$ & 1 & & \\
\hline P & NS & NS & NS & NS & $-0.591^{*}$ & $0.749^{*}$ & $0.522^{*}$ & & \\
\hline$K$ & NS & NS & NS & NS & $-0.658^{*}$ & $0.594^{*}$ & NS & 1 & \\
\hline CEC & $0.640^{*}$ & $0.633^{*}$ & $-0.775^{*}$ & NS & NS & NS & NS & $0.596^{*}$ & \\
\hline $\mathrm{Ca}^{+2}$ & NS & NS & NS & $0.891^{\text {** }}$ & NS & NS & $-0.528^{*}$ & NS & 1 \\
\hline $\mathrm{Mg}^{+2}$ & NS & NS & NS & $0.807^{\star *}$ & NS & NS & NS & NS & $0.910^{* *}$ \\
\hline
\end{tabular}

* Significant at 5\% level; ** Significant at 1\% level

\section{Physicochemical Properties under Non-organic Tea Growing Soils of Darjeeling}

The non-organic tea growing soils of Darjeeling districts were strong to moderately acidic in reaction with $\mathrm{pH}$ ranging from 4.51 to $5.33,4.33$ to 5.09 and 4.44 to 5.44 in low, medium and high elevations respectively [Table-7]. The EC of all the soils were low. The texture of the soil under study varied from sandy loam to clay but most of the soils were sandy loam in texture. The clay content varied from 14.8 to $35.2,18.0$ to 41.2 and 7.6 to 29.2 percent under low, medium and high elevations respectively. The organic carbon was medium to high, varying from 18.7 to $28.7,16.5$ to 27.9 and 18.2 to $30.2 \mathrm{~g} \mathrm{~kg}^{-1}$ under low, medium and high elevations respec-

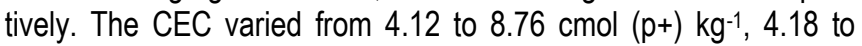

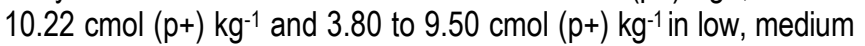
and high elevations respectively. The available soil nitrogen content was very low to low and it may be due to less inputs of fertilizer nitrogen and or organic amendments. The available $P$ content of the soils varied widely from low to high. It was from 78.96 to 152.12 $\mathrm{kg} \mathrm{ha}^{-1}$ in low, 18.61 to $167.93 \mathrm{~kg} \mathrm{ha}^{-1}$ in medium and 62.35 to $180.03 \mathrm{~kg} \mathrm{ha}^{-1}$ in high elevations respectively. The available $\mathrm{K}$ content in soils varied from 173.88 to $326.12 \mathrm{~kg} \mathrm{ha}^{-1}$ in low, 122.56 to $445.57 \mathrm{~kg} \mathrm{ha}^{-1}$ in medium and 86.94 to $225.13 \mathrm{~kg} \mathrm{ha}^{-1}$ in high elevations respectively. These large variations in available $\mathrm{K}$ content might be due to the non-uniform application of $K$ fertilizers. The $\mathrm{Ca}^{+2}$ and $\mathrm{Mg}^{+2}$ content in soils were low due to the surface leaching of basic cations by the excessive rainfall. The steep terrain physiography sustain quick run off of surface water.

Table 7- Important physicochemical properties under non-organic tea growing soils $(0-20 \mathrm{~cm})$ of Darjeeling

\begin{tabular}{|c|c|c|c|c|c|c|c|c|c|c|c|c|c|}
\hline $\begin{array}{l}\text { Name of the } \\
\text { Gardens }\end{array}$ & $\begin{array}{l}\text { levation } \\
\text { (mt) }\end{array}$ & $\begin{array}{l}\text { Clay } \\
(\%)\end{array}$ & $\begin{array}{l}\text { Silt } \\
(\%)\end{array}$ & $\begin{array}{l}\text { Sand } \\
(\%)\end{array}$ & $\underset{(1: 2.5)}{\mathrm{pH}}$ & $\underset{\left(d S m^{-1}\right)}{E C}$ & $\begin{array}{c}\text { Organic Carbon } \\
\left(\mathrm{g} \mathrm{kg}^{-1}\right)\end{array}$ & $\begin{array}{l}\text { Available-N } \\
\left(\mathrm{kg} \mathrm{ha}^{-1}\right)\end{array}$ & $\begin{array}{c}\text { Available-P } \\
\left(\mathrm{kg} \mathrm{ha}^{-1}\right)\end{array}$ & $\begin{array}{c}\text { Available-K } \\
\left(\mathrm{kg} \mathrm{ha}^{-1}\right)\end{array}$ & $\begin{array}{l}\text { CEC [cmol } \\
\left.(\mathrm{p}+) \mathrm{kg}^{-1}\right]\end{array}$ & $\begin{array}{l}\mathrm{Ca}^{+2}\left[\mathrm{cmol}^{-}\right. \\
\left.(\mathrm{p}+) \mathrm{kg}^{-1}\right]\end{array}$ & $\begin{array}{c}\mathrm{Mg}^{+2}\left[\mathrm{cmol}^{-1}\right. \\
\left.(\mathrm{p}+) \mathrm{kg}^{-1}\right]\end{array}$ \\
\hline & 444 & 21.2 & 25.6 & 53.2 Sandy Clay Loam & 4.74 & 0.12 & 28.7 & 75.26 & 88.86 & 213.01 & 4.12 & 0.08 & 0.02 \\
\hline \multirow[t]{3}{*}{ Glenburn } & 617 & 25.2 & 29.6 & 45.2 Clay Loam & 4.59 & 0.11 & 27.9 & 66.48 & 167.93 & 122.56 & 7.60 & 0.17 & 0.02 \\
\hline & 916 & 29.2 & 21.6 & 49.2 Clay Loam & 4.44 & 0.14 & 24.1 & 69.23 & 62.35 & 86.94 & 8.12 & 0.04 & 0.03 \\
\hline & 495 & 35.2 & 39.6 & 25.2 Clay & 4.51 & 0.21 & 20.3 & 48.92 & 78.96 & 173.88 & 4.22 & 0.05 & 0.02 \\
\hline \multirow[t]{3}{*}{ Bernesbeg } & 731 & 41.2 & 35.6 & 23.2 Clay & 4.33 & 0.11 & 22.5 & 66.48 & 18.61 & 445.57 & 10.22 & 0.06 & 0.01 \\
\hline & 849 & 7.6 & 32.0 & 60.4 Sandy Loam & 4.53 & 0.09 & 30.2 & 112.36 & 180.03 & 225.13 & 9.50 & 0.05 & 0.06 \\
\hline & 624 & 14.8 & 24.2 & 61.0 Sandy Loam & 5.13 & 0.13 & 18.8 & 56.24 & 152.12 & 326.12 & 8.76 & 0.12 & 0.02 \\
\hline \multirow[t]{2}{*}{ Namring } & 814 & 18.0 & 29.6 & 52.4 Sandy Loam & 5.09 & 0.14 & 16.5 & 56.45 & 82.34 & 1.26 .12 & 4.18 & 0.18 & 0.04 \\
\hline & 1066 & 25.2 & 25.6 & 49.2 Clay Loam & 5.44 & 0.11 & 18.2 & 58.96 & 103.73 & 122.36 & 3.80 & 0.17 & 0.23 \\
\hline
\end{tabular}

Table 8- Correlation matrix among soil physicochemical properties under non-organic tea growing regions of Darjeeling

\begin{tabular}{lccccccc} 
Soil Properties & Clay & Silt & Sand & pH & EC & OC & K \\
Sand & $-0.922^{* *}$ & $-0.724^{*}$ & 1 & & & & \\
pH & NS & NS & $0.497^{*}$ & 1 & & & \\
EC & NS & NS & NS & $-0.681^{*}$ & 1 & & \\
OC & $0.514^{*}$ & NS & NS & $-0.652^{*}$ & NS & 1 & \\
N & $0.633^{*}$ & $0.506^{*}$ & $-0.690^{*}$ & NS & NS & $0.776^{*}$ & \\
K & $0.648^{*}$ & NS & $-0.632^{*}$ & NS & NS & NS & 1 \\
CEC & $0.754^{*}$ & $0.561^{*}$ & $-0.804^{* *}$ & NS & NS & NS & $0.539^{*}$ \\
Ca+2 & NS & $-0.533^{*}$ & $0.523^{*}$ & $-0.696^{*}$ & $-0.634^{*}$ & NS & NS \\
\hline
\end{tabular}

* Significant at $5 \%$ level; ** Significant at $1 \%$ level
The clay content had a significant positive correlation [Table-8] with OC $\left(r=0.514^{*}\right)$, available $N\left(r=0.633^{*}\right)$, available $\mathrm{K}\left(r=0.648^{*}\right)$ and CEC $\left(r=0.754^{* *}\right)$. The silt had a significant positive correlation with available $\mathrm{N}\left(\mathrm{r}=0.506^{*}\right)$ and CEC $\left(\mathrm{r}=0.561^{*}\right)$ and negatively with calcium $\left(r=-0.533^{*}\right)$. The soil pH had a significant negative correlation with EC $\left(r=-0.681^{* *}\right)$, organic carbon $\left(r=-0.652^{*}\right)$ and $\mathrm{Ca}^{+2}$ content $\left(r=-0.696^{*}\right)$. Strong and positive correlation was observed between organic carbon and available $\mathrm{N}\left(\mathrm{r}=0.776^{\star *}\right)$, indicating the availability of nitrogen as influenced by the soil organic carbon. 


\section{Conclusion}

It was observed that different pedogenic processes and related physiography of the tea-growing areas (differences in plant age, elevation, organic and non-organic inputs) had influences on the physicochemical characteristics of the soils (texture, nutrients availability, cation exchange capacity and organic carbon content of the soils). Therefore, this would help taking up appropriate measures on the problem of the tea soils of West Bengal. However, application of more labile organic inputs, liming materials and suitable inorganic fertilizers (N-P-K) would be effective for sustainable management and improving fertility status of the soils under teagrowing region.

\section{References}

[1] Jana M.M. (1994) Workshop of River Behaviour in the North Bengal Rivers, North Bengal University, India.

[2] Hadfield W. (1968) Nature, 219, 282-284.

[3] Jana M.M. (1997) Journal of the Indian Society of Remote Sensing, 25, 105-111.

[4] Page A.L., Millner R.H., Keeney D.R. (1982) Method of Soil Analysis, Part 2: Chemical and Microbiological Properties, 2nd ed. ASA and SSSA, Madison, Wisconsin. 